Article

\title{
Evolution of Flood Defense Strategies: Toward Nature-Based Solutions
}

\author{
Yen-Yu Chiu ${ }^{1,2,3}$, Nidhi Raina ${ }^{1}$ (D) and Hung-En Chen ${ }^{1,3, *(D)}$ \\ 1 Water Science and Engineering Department, IHE Delft Institute for Water Education, \\ 2611 AX Delft, The Netherlands; ciu0519.cv98g@g2.nctu.edu.tw (Y.-Y.C.); nidhiraina3@gmail.com (N.R.) \\ 2 Department of Civil Engineering, National Chiao-Tung University, Hsinchu 30010, Taiwan \\ 3 Department of Soil and Water Conservation, National Chung Hsing University, Taichung 40227, Taiwan \\ * Correspondence: hechen@g2.nctu.edu.tw
}

check for updates

Citation: Chiu, Y.-Y.; Raina, N.; Chen, H.-E. Evolution of Flood Defense Strategies: Toward Nature-Based Solutions. Environments 2022, 9, 2 https://doi.org/10.3390/ environments 9010002

Academic Editor:

Zacharias Frontistis

Received: 26 September 2021

Accepted: 15 December 2021

Published: 23 December 2021

Publisher's Note: MDPI stays neutral with regard to jurisdictional claims in published maps and institutional affiliations.

Copyright: (C) 2021 by the authors. Licensee MDPI, Basel, Switzerland. This article is an open access article distributed under the terms and conditions of the Creative Commons Attribution (CC BY) license (https:// creativecommons.org/licenses/by/ $4.0 /)$.

\begin{abstract}
Flood defense strategies have evolved from hard-engineered systems to nature-based solutions that advocate for sustainability to meet today's environmental, social, and economic goals. This paper aims to analyze the historical progression and evolutionary trends in flood control strategies that have led to nature-based solutions. An evaluative literature review was conducted to narrate the evolution of nature-based flood management approaches for different flood types, river floods, coastal floods, and stormwater run-offs. The analysis reflected three evolutionary trends: the transformation of hard measures to soft measures; secondly, the increase in society's attention to ecosystems and their services; and, finally, divergence from single-function solutions to multi-function solutions. However, continuous monitoring and evaluation of the previous projects and adapting to the lessons learned are the key to progress towards sustainable flood management strategies and their societal acceptance.
\end{abstract}

Keywords: nature-based solutions; flood defense strategies; green infrastructure; ecosystem-based approaches; building with nature

\section{Introduction}

Throughout human history, the availability of water resources has been essential to humans' well-being and survival [1]. The convenience of accessing water has been a critical determinant of human settlements near water bodies. However, these settlements near the water bodies have faced severe risks, such as floods, which could become more threatening under future climatic and socio-economic vulnerabilities. Several approaches have been tried and tested to cope with flood disasters over time. Traditional engineering solutions, commonly called 'grey infrastructures', are considered practical measures and have been used as defenses against different types of floods. Hard-engineered systems, such as seawalls, dikes, levees, pumping facilities, floodways, etc., and stormwater management strategies, such as gutters, storm sewers, tunnels, culverts, detention basins, etc., are some of the grey infrastructures that have been used for preventing coastal and river floods. The benefits of grey infrastructure are that it allows standardization and replication of the engineered systems, which significantly reduces the project costs and delivery times and, thus, ensures high performance standards. However, these systems also require continual maintenance and often need to be renovated periodically.

In recent years, pressures on the quality and the quantity of water resources and unprecedented flood risks have increased drastically. The current global issues, such as increased urbanization, higher run-off volumes, and climate change, have put a strain on the existing hard systems; thus, they have increased their designing, operating, and maintaining costs [2]. Consequently, sustainable water management and flood resilience have become critical challenges for coastal areas and the surrounding cities. The problems have particularly escalated in the face of climate change that impacts rainfall patterns, 
intensities, and frequencies. Extreme precipitation events could produce frequent run-offs, which could exceed the capacities of current urban drainage systems. Therefore, areas along the rivers or the coastlines and inland areas that are not in vicinity of a water body are being threatened by increased risks of flooding, rising sea levels, and uncertain precipitation patterns [3].

The current climate and socio-economic conditions changes call for smart, naturebased developments and innovations in flood and water management. The idea of the sustainable use of nature to meet the current environmental, social, and economic challenges is referred to as 'nature-based solutions' (NBS) [4]. The term NBS was mentioned by the World Bank [5] and further defined by IUCN [6] and then explained more explicitly by the European Commission [7]. NBS have been described by Cohen-Shacham et al. [8] as "actions to protect, sustainably manage and restore natural or modified ecosystems, which address societal challenges (e.g., climate change, food, and water security or natural disasters) effectively and adaptively, while simultaneously providing human well-being and biodiversity benefits". NBS have been reported as efficient tools to tackle flood risks, water security, and water quality issues by using a wide range of processes, such as mimicking natural processes of infiltration, evapotranspiration, and phytoremediation.

The overall objective of the concept of NBS and other similar terms used for flood management (such as ecosystem-based management, eco-friendly flood protection, sustainable flood management, natural flood management, etc.) is to meet the needs for resilience against flooding. The concept aims to enhance community benefits (social objective), protect nature (environmental objective), and deliver resilience at an affordable cost (economic objective) [9]. Sustainability in flood management is challenging to achieve with state-ofthe-art civil or hydraulic engineering in some intractable cases. Hence, interdisciplinary co-operation is needed.

In recent decades, many innovative flood defense strategies have emerged globally to solve the different flood problems. These strategies, such as 'building with nature' (BwN), 'low impact development' (LID), 'sustainable drainage systems' (SUDS), 'green infrastructure' (GI), water-sensitive urban design (WSUD), sponge city, etc., have emphasized sustainability, resilience, and climate change adaption. Even though abundant literature exists for these solutions, only limited studies discuss the evolution of these approaches. Ecological engineering (EE), a coin termed by Odum in 1989, was the earliest step in initiating ecosystem-based approaches to flood management, which focused on waste clean-up and management (as cited in [10]). By the late 1990s, the term EE evolved to describe the design of sustainable ecosystems [11].

Similarly, the term GI was widely popularized during the late 1990s to identify, protect, and restore interconnected urban greenspaces; however, the concept was further developed by the USEPA to manage stormwater and polluted run-off [12], using natural or engineered systems to mimic natural systems. GI and LID are increasingly used in combination for stormwater management, e.g., by the USEPA [13]. Similarly, BwN initially aimed for coastal spatial optimization [14], and, today, it has expanded to designing flood safety measures for rivers and cities. In addition to the lack of evolution of flood management terminologies in literature, newer approaches, such as $\mathrm{BwN}$, have not been mentioned very often. Therefore, this study also elucidates on the ongoing European project 'Building with Nature', funded by the Interreg North Sea Region Programme (2014-2020). The project aimed to use NBS principles to make the North Sea region's coasts, estuaries, and catchments more adaptable and resilient to the effects of climate change.

Thus, the objective of our study is to review and analyze the evolution of nature-based solutions for flood control strategies. Flood-prone areas are classified, and evolutions in these areas are reviewed separately. The study also tries to indicate the common changes of these areas, and it shows that all the areas are moving towards NBS from the existing structural flood control strategies. The paper is organized as follows: Section 2 defines the methodological approach of reviewing NBS literature. Section 3 onwards describes the results obtained from the literature review and highlights the historical progression of 
flood defenses. Section 4 describes the evolutionary trends in flood management. Section 5 analyzes how NBS differ from traditional solutions in the objectives and functions. The paper concludes in Section 6 and ends on a take-away note for the readers.

\section{Materials and Methods}

This study was conducted using an extensive evaluative literature review. Existing research and practical cases were the major materials of the study. Specific scientific publications, policy briefs, and project reports were then targeted for an in-depth review and important points regarding each flood types and NBS approaches were noted. Since the Interreg North Sea region funded BwN projects have also been researched and mentioned across the study, the project website (https:/ / northsearegion.eu/building-with-nature/ (accessed on 20 August 2021)) was used for the data and publications. Literature of the topics related to historical developments of flood management, information about different types of NBS, and studies on flood risks and infrastructure for defenses were collected and analyzed for trends in flood management strategies which could have led to the evolution of NBS. In addition, since it is a review of the evolution of management strategies, older publications not available on the internet were extracted from different sources and requested from the organization so that missing details or misinformation were avoided.

\section{Flood Typologies and Related NBS Approaches}

An extensive non-systematic literature review into flood management strategies and NBS approaches was conducted to highlight the different flood typologies and analyze specific typologies in this study. The NOAA National Severe Storms Laboratory (NSSL) lists five types of floods on its website (https:/ / www.nssl.noaa.gov/education/svrwx1 01/floods/types / (accessed on 11 November 2021)). These include 'river floods', 'coastal floods', 'storm surges', 'inland floods', and 'flash floods.' A handbook on good practices for flood mapping [15] in Europe broadly classified different types of floods as 'river flooding in flood plains', 'seawater flooding', which includes storm surges, 'mountain torrent activity or rapid run-off from hills', 'flash floods', 'groundwater flooding', and 'lake flooding'. Finally, IPCC's 2012 report classified floods as 'fluvial floods', 'flash floods', 'urban floods', 'pluvial floods', 'sewer floods', 'coastal floods', and 'glacial lake outburst floods'. This study extracted coastal floods (including storm surges), river floods (i.e., fluvial floods), and stormwater run-off (pluvial floods, surface water floods, flash floods, etc.) based on the literature reviewed and tried to correlate the flood types to different regions of a landscape. For example, river floods are a characteristic of inland water bodies, such as a river or a lake. Different management approaches for each flood type were reviewed from the literature in the following sections and presented comprehensively in Table 1 below. Only nature-based management approaches were reported for each flood type, and their multi-functionality was highlighted. 
Table 1. Classification of different flooding areas and corresponding NBS approaches.

\begin{tabular}{|c|c|c|c|c|}
\hline Flooding Area & Flood Typology & Flood Characteristics & $\begin{array}{c}\text { Corresponding NBS } \\
\text { Approaches }\end{array}$ & Multiple Functions \\
\hline Coastal areas & Coastal floods & $\begin{array}{l}\text { Storm surge and tsunamis can } \\
\text { cause inundation of seawater's } \\
\text { land areas along the coast, which } \\
\text { causes coastal flooding. Usually, } \\
\text { water overwhelms the coasts, } \\
\text { which are low-lying areas, and } \\
\text { can cause coastal erosion, } \\
\text { massive destruction of property, } \\
\text { and loss of lives. }\end{array}$ & $\begin{array}{l}\text { BwN ecosystem- } \\
\text { based coastal defense } \\
\text { (e.g., sandy } \\
\text { nourishments) }\end{array}$ & $\begin{array}{c}\text { Coastal erosion } \\
\text { prevention, habitat } \\
\text { restoration, } \\
\text { biodiversity } \\
\text { conservation }\end{array}$ \\
\hline $\begin{array}{c}\text { River areas } \\
\text { (including all } \\
\text { freshwater bodies } \\
\text { inland to the cities) }\end{array}$ & River floods & $\begin{array}{l}\text { Increased water levels of a river } \\
\text { or a lake due to excessive rain } \\
\text { or snowmelt can overflow onto } \\
\text { the surrounding banks and } \\
\text { neighboring lands, causing river } \\
\text { floods. Usually, precipitation } \\
\text { levels, river levels, and terrain } \\
\text { conditions are considered when } \\
\text { forecasting river floods. }\end{array}$ & $\begin{array}{l}\text { River restoration (e.g., } \\
\text { river re-meandering), } \\
\text { BwN (e.g., 'room for } \\
\text { the river' program) }\end{array}$ & $\begin{array}{l}\text { Riverbank erosion } \\
\text { prevention, river } \\
\text { structure damage } \\
\text { mitigation, habitat } \\
\text { restoration }\end{array}$ \\
\hline $\begin{array}{l}\text { Built environments } \\
\text { (including both } \\
\text { rural and urban } \\
\text { settings) }\end{array}$ & $\begin{array}{l}\text { Stormwater } \\
\text { run-offs }\end{array}$ & $\begin{array}{l}\text { A stormwater run-off occurs } \\
\text { when an extreme precipitation } \\
\text { event leads to a flood even in the } \\
\text { absence of an overflowing water } \\
\text { body in the vicinity. They are } \\
\text { most common in built } \\
\text { environments of rural or urban } \\
\text { areas. Flash floods are a type of } \\
\text { stormwater run-off caused by } \\
\text { high intensity of rainfall within a } \\
\text { short period. Devastating } \\
\text { torrents characterize them after } \\
\text { heavy rain in an area. }\end{array}$ & $\begin{array}{l}\text { GI, LID, SUDS, } \\
\text { sponge city }\end{array}$ & $\begin{array}{c}\text { Water source } \\
\text { protection, water } \\
\text { pollution control, water } \\
\text { quality improvement }\end{array}$ \\
\hline
\end{tabular}

\subsection{Coastal Areas}

Coastal management aims to protect the shore from sea level rise and storm surges and create a defense against flooding and erosion. The history of coastal engineering is not easily traceable and might have existed since the time man inhabited the coastal areas [16]. The first recorded beach nourishment project was in the United States at Coney Island, New York, in 1923 [17]. Even though it was a large project, the design was just rudimentary dumping of sand on the beach, which integrated 2 miles of shoreline. This new shoreline helped the county gain economic benefits by creating a new recreational area [17]. There have been significant advances in planning, monitoring, and maintenance of beach nourishment projects [18]. In recent decades, artificial nourishment has been promoted as one of the significant coastal defense schemes, mainly because of its cost-effectiveness and technical improvements [19]. Sand nourishment can be in the form of dune reinforcement, beach nourishment, and shoreface nourishment. However, several studies have pointed out an increasing demand to maintain consistent nourishment [20,21].

For sustainable management of coastal areas, 'integrated coastal zone management' (ICZM) was introduced in 1992 during the Earth Summit at Rio de Janeiro. The European Commission [22] describes ICZM as a sustainable process for coastal management that is multidisciplinary, iterative, and dynamic. The principles of ICZM emphasize incorporating the functions of natural processes while respecting the carrying capacity of ecosystems to achieve sustainability [22]. The need for protection strategies and infrastructures has increased as societies continue to urbanize rapidly, and coastal areas are becoming more 
vulnerable to sea level rise and other extreme weather events [23]. The need for sustainable coastal protection arose from the thought that hard engineering systems may increase societies' vulnerabilities in the long run [24]. In recent years, ecosystem-based coastal management solutions are being used as a regional solution since they are more sustainable and cost-effective than conventional engineering methods [25]. Under ICZM principles, many BwN approaches are being implemented in coastal areas. The BwN strategy utilizes natural processes and materials to bring additional benefits to the communities, such as recreational and economic benefits, while restoring the coast. The $\mathrm{BwN}$ principles have been gradually spreading over Europe and Asia since 2002 [26,27]. In the Netherlands, around 1000 hectares of coastline have been reclaimed using the $\mathrm{BwN}$ principles with sand dunes and beaches [14]. The Delfland Sand Engine project (2006-2011), Netherlands, was an experimental coastal maintenance project using mega-nourishment concentrated in time and space [28]. It was expected to reduce the engineering and construction costs, create a more natural coastal profile in the long run, and provide several ecological and recreational benefits to the societies along the coasts, thus using core BwN principles. Five years after its implementation, monitoring and evaluating the project show positive results and multiple benefits, including improved coastal protection, room for new habitats, new dunes, and leisure and safety for visitors, as hypothesized [29].

\subsection{River Areas}

River restoration was initiated around the 1970-1980s, particularly for water quality issues and good ecological status. River restoration started being applied as a flood protection mechanism only in the late 1990s [30]. After the devastating floods in the 1990s $(1993,1995,1997)$, the European Union started to value their river systems more from the perspectives of flood events [31]. This was reflected in the EU's flood directive of 2007. Political agendas focused on the re-development of natural rivers and their courses [32]. During the same period, researchers attributed the causes of flood disasters to the loss of wetlands and floodplains. Thus, it started to promote river restoration for both ecological value and flood reduction $[33,34]$. At the same time, many case studies highlighted the disadvantages of traditional flood management for river areas, such as longer implementation time [35], maladaptation to climate change with energy-intensive structures, such as desalination plants, or high construction and maintenance costs for structures, such as riverine dikes [36]. Speed et al. [30] suggested that interventions blend conventional engineering with other disciplines such as ecology. Thus, river restoration is now considered to be more than just the building of traditional hard structures such as tall and heavy dikes, but also aims at restoring ecosystem functioning. For instance, the 'Room for the River' project was proposed in 2006 by the Dutch cabinet [37]. The project planned to modify the existing structures of different floodplains that encompass the four rivers: the Rhine, the Meuse, the Waal, and the Ijssel. This project included a combination of centralized and decentralized governance approaches for water management [38]. This project has become one of the major contributions of the $\mathrm{BwN}$ approach. Thus, the BwN approach also aims to improve the safety of riverine areas from flooding and to improve the spatial quality of the riverine regions.

River restoration today aims to increase natural storage capacity and reduce flood risks by re-connecting streams and rivers to floodplains, restoring the original meandering river morphologies, and re-constructing wetlands. The river restoration process can be of two types: active restorations, which include physically changing the river landscape, and passive restoration, which provides for altering policies to affect human behavior [30] indirectly. River restoration has evolved from the one-dimensional response, such as water quality, to inter-related issues, such as flash flooding and ecosystem degradation. This evolution is a consequence of adopting the NBS principles. 


\subsection{Built Environments}

Traditional urban drainage systems have been used to control floods and to store rainwater since the third millennium BC [39]. Urban drainage systems were integrated with the aqueducts in ancient Rome (eighth century $\mathrm{BC}$ ) to create an urban water cycle structure that could import freshwater into cities and protect the low-lying areas from excessive rainfall [40]. The modern urban drainage systems were first instilled in the nineteenth century in western Europe [40], which helped prevent flooding and drainage through a system of catch basins and pipes which efficiently delivered the run-off to the nearest water bodies [41]. However, flaws with these systems were soon realized, including severe downstream flooding and bank erosions [41]. Moreover, flood disasters also degraded the water quality. By the 1970s, flow control structures, such as detention basins, were installed, which had issues such as clogging. Thus, the recent goal of stormwater management has been to manage the volume of the urban run-off to avoid flooding and better the water quality of the cities [42]. This marked the beginning of sustainable designs for stormwater management which could manage the stormwater as close to the source as possible. Landscape architect Ian McHarg [43] came up with a conservation design for stormwater management called low impact development (LID) in 1975. This included rain gardens, disconnected roof drains, porous pavement, narrower streets, grass swales, etc., for maintaining the stormwater closer to the source and, thus, avoiding run-offs. Since the 1980s, other techniques, such as best management practices (BMP), 'green infrastructure' (GI), 'sustainable urban drainage system' (SUDS), 'water-sensitive urban design' (WSUD), 'sponge city,' etc., started emerging around the globe with similar principles and processes.

Many studies, such as those of Fletcher et al., Kabisch et al., Mguni et al., Raymond et al., Zhou, etc. [13,36,44-46], documented these terminologies and explained the significant overlaps and differences between these terminologies. There is a growing focus on the sustainability aspects of stormwater management, which could include natural hydrological processes and considers the multiple benefits of these techniques on society and the environment. For example, the LID has been defined as the interaction of natural process with the urban systems to protect water quality and aquatic ecosystems [12]. The modern urban drainage systems are also being referred to as SUDS, which have focused on employing science and engineering disciplines to ensure economic, social, ecological, and environmental sustainability [47]. The present popular NBS techniques include filter and infiltration trenches, permeable surfaces, water storage, swales, water harvesting, detention basins, wetlands, and ponds [48-50].

Thus, the progression of flood management strategies in different risk areas highlights how different NBS are being accepted and implemented. Looking at the progression of strategies from grey to green infrastructure, three key trends were observed about NBS that are discussed in the next section.

\section{Evolutionary Trends in Flood Management}

Three major trends are recognized from different flood management approaches. The first trend is the transformation of flood control strategies from traditional measures to more sustainable measures or soft measures, which consider the role of natural processes in coping with flood risks. The second trend defines how peoples' willingness and consideration towards the importance of the ecosystem and its services has increased ecosystem-based adaptation to natural disasters. The last trend depicts the evolution of single-function strategies into multi-functional strategies for flood control. These trends belong to three different changes: the change of the application materials and measures, the change of social requirements and concepts, and the change of functions provided. The following sub-sections describe these trends in more detail.

\subsection{The First Trend: The Transformation of Hard Measures into Soft Measures}

The evolution of flood defense strategies for each flood type was explained with a timeline constructed from the 1900s to the present, 2020, marking essential milestones. 
Figure 1 below depicts the timeline that indicates the gradual transformation of coastal defense strategies: from hard structures to nature-based strategy for the different flood types. The dawn of modern flood control began in the 1900s [51].

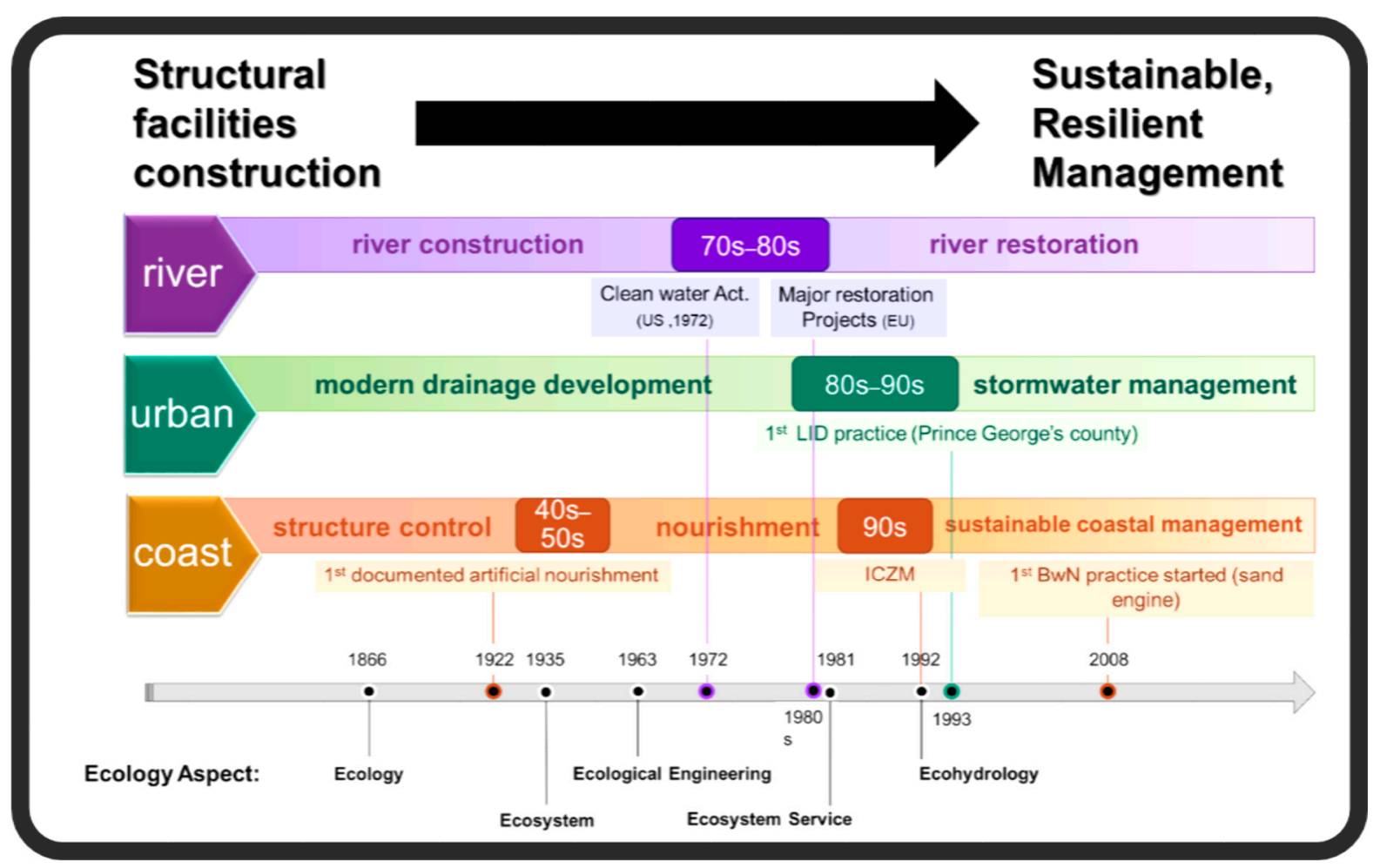

Figure 1. The evolutionary trends of flood strategies in the river, urban, and coastal area.

Flood control during the early 1900s was more about protecting an individual area than understanding the benefits of harnessing the floods. Extreme floods in the US in the 1920s, in China during the 1930s, 1940s, and 1950s, and in Europe during the late 1950s pushed societies to build sturdier dams, raise dikes, etc., and reminded them of the fragility of structural defenses. Finally, in the 1980s, the UN put forward sustainable development, which directed flood management solutions towards a mix of hard and soft measures. This idea was backed mainly by developed countries, such as the United States [51], many European countries [52,53], Australia, and Japan [54], which had started working on various flood control strategies before the 1980s. This is evident in the timeline of different flood control terminologies that evolved globally (Figure 1). By the 1990s, developing countries, such as China, also realized the need for approaches that work in harmony with natural flood processes [54]. For instance, 'sponge city' has become a popular expression in China [55]. One major underlying reason for the global transformation was the increase of social awareness that the impact of natural hazards might be irreversible [54]. Sayers et al. [50] observed that beliefs, policies, and practices had been learned from the past flood events, e.g., flood events in the 1990s on the Rhine and in the UK, the Asia tsunami in 2004, and 2005 in New Orleans, USA. These disasters enforced that hard structures, such as levees, were failing in flood protection, and, thus, countries across the globe started to combine structural and non-structural approaches for sustainable flood management [56]. Thus, 1990s saw a global emergence of sustainable, nature-based, ecosystem-led solutions (such as land use changes, wetland storage, and floodplain reconnection) for coastal floods, riverine flooding, and urban drainage systems.

However, the effectiveness of the implementation of the NBS is still unclear and not fully quantified, and that is why they are not yet mainstreamed for global usage. Thus, these approaches need to be tested according to engineering standards for the probability 
of failure. Even though hard structures are still being constructed, their environmental impact assessment is now a pre-requisite, which can pave the way for testing with newer NBS. One of the significant barriers to this implementation is societal acceptance of NBS, which we discuss in the following sub-section.

\subsection{The Second Trend: Increase in Society's Attention towards Ecosystem-Based Adaptation}

Ecological and environmental studies are relatively new compared to the development of hydraulic and civil engineering. The term 'ecology' was first coined by Hackel in 1866, and Tansley first introduced 'ecosystem' in 1935. Traditional 'hard-engineered' infrastructure and adaptation measures are being rendered as inflexible, unsustainable, and expensive in the past decades [57-59]. The value of natural resources and nature-based engineering is thus being recognized. This has led to the emergence of "ecosystem-based adaptation" (EbA), which can be a comprehensive, multi-functional, and potentially costefficient form of natural flood management [57]. EbA is not only a tool for climate change adaptation, but it also offers a 'no-regret' solution for other co-benefits. EbA has been evolving under the umbrella of NBS since $1995[57,58]$ and has worked towards societal resilience. However, ecological values and societal development have been contradictory since the beginning. The attention to EbA has brought in more research and related practices in the engineering fields; however, public perception has not favored $\mathrm{EbA}$ and has met with 'NBYism' (not in my backyard-ism) [60]. For example, the idea of turning valuable land into tidal marshes has been met with social and political objections in the Netherlands [25]. The socio-economic factors might be why ecosystem-based defenses have been implemented majorly in Europe and the United States and only on more minor scales in Asia [25]. However, citizen engagement [61], community education [62], and public communication [63] have shown promising results on public acceptance of EbA. This approach can also be experimented with for NBS. Santoro et al. [64] studied stakeholder risk perception for implementing NBS for flood protection at the Glinščica river (Slovenia). The study concluded that, even though stakeholders needed the quantitative assessment of the effectiveness of NBS measures for supporting the approach, qualitative scenarios were considered suitable for supporting the initial discussion. Thus, public perception can be changed in favor of NBS, provided they are included in some or all the stages of implementation of these approaches. One of the major points that can tip the scale in favor of NBS, other than risk perception, is the multiple benefits provided by these approaches, which are discussed below.

\subsection{The Third Trend: From a Single Objective Solution to a Multi-Objective Solution}

As discussed above, the increasing global flood risks cannot be solved with a single solution or a management strategy. Literature and case studies have highlighted how NBS can mitigate floods and provide multiple benefits to the area and local communities [22,54-57], such as enriching biodiversity, improving landscape benefits, creating more jobs, soil erosion control, delivering public goods, etc. The multi-functionality of NBS is accredited to the inter-disciplinary knowledge of ecosystem-related fields that combine the interactions of water and ecosystems, such as water ecology, ecological engineering, and eco-hydrology, which have provided innovations to solve flood-related problems [58,59]. The switch to inter-disciplinary solutions has been triggered by the weaknesses of the traditional flood defense methods. However, without advanced knowledge of ecological engineering, this transformation is unlikely to happen $[60,65]$. Thus, understanding the ecological complexity of local ecosystems is the first step towards developing a suitable NBS for that area. However, evaluation of the impact of NBS on the ecosystem is also necessary to understand its interplay with the whole ecosystem. This can also help understand the multi-functionality of a NBS approach. The Eddleston Water Project (in Scotland), under the Interreg BwN project, tried to achieve natural flood management and monitor the biodiversity of the catchments while working with stakeholders, such as farm businesses and governments. 


\section{Edge of Nature-Based Solutions}

The trends in Section 3.2 reveal some buzzwords that are becoming the stakeholders' demands for flood control strategies: resilience, sustainability, and multi-functions. The encompassing literature we reviewed in Section 3 also shows that NBS are the emerging solution for the coastal, river, or built environments areas and have a certain edge over traditional the grey solutions that are further discussed in this section.

However, a big issue is converting state-of-the-art to NBS instantly. In the early stages, NBS are likely to be considered as a radical novelty. Still, the delineation of the boundaries of the technologies is particularly problematic (i.e., low levels of coherence). For example, the $\mathrm{BwN}$ approach was limited to coastal areas when it was initiated, but it has recently expanded to the riverine areas. Additionally, newer practices in this field are emerging at a fast pace. So, with the increasing applications of these practices, the definitions of these strategies have become more explicit with fewer uncertainties. Many NBS used in stormwater management have different terminologies depending on the regions they were established in; however, the concepts are profoundly similar, such as sustainable drainage systems (SuDS) in the United Kingdom, which are a similar concept to water-sensitive urban design (WSUD) in Australia. On the contrary, the most avant-garde idea of BwN has not reached its final stage since several types of research and experimental applications are yet ongoing, and, thus, its uncertainties are high.

In general, NBS have the edge over traditional solutions in many criteria. In theory, NBS aim to design a resilient and multi-functional infrastructure that works interconnectedly with vulnerable areas for a longer duration than their grey counterparts. NBS approaches try to have sustainable and adaptive resilience-based planning and designing processes compared to grey solutions that are risk-based and robust but for shorter durations.

Traditional solutions, basically generally referring to those concrete structural control solutions (dikes, revetments, etc.), have been adopted for decades but showed some common disadvantages in both flood resistance and environmental issues (Table 2). Summarizing the disadvantages of the three areas, the most common problem is the flood problem transfer to another adjacent area and the destruction of landscape and ecosystems. Literature ([66-69]) also showed that the two major reasons for replacing traditional methods can be, firstly, that these traditional methods are not enough to reduce the flood risks in the face of changing climatic and socio-economic conditions. Secondly, that the traditional methods have a negative impact on the environment.

Table 2. Summary of disadvantages of traditional methods for different flood areas.

\begin{tabular}{ccc}
\hline Area & Flood Risks & Environmental Issues \\
\hline Coastal Areas & $\begin{array}{c}\text { Instead of damping wave energy, deflect it to } \\
\text { adjacent areas. Wave action erodes soil or sand } \\
\text { at the base of a wall and causes it to collapse. } \\
\text { The hydraulic conditions and the balance of } \\
\text { sand transport were changed, which } \\
\text { transferred the problems upstream and } \\
\text { downstream. }\end{array}$ & $\begin{array}{c}\text { The ecosystem and social and } \\
\text { biological habitats are destroyed } \\
\text { Waterfront landscape destruction }\end{array}$ \\
Built Environments & Severe downstream flooding. & Green spaces disappear \\
\hline
\end{tabular}

The general objective of all NBS flood control methods is to manage the amount of water or the energy flow or the wave during flooding or rainfall events (Table 3). However, the traditional solutions and the NBS have entirely different approaches to coping with flood events. The general strategies of traditional solutions may be simplified into three principles: (1) to restrict the water by structures, (2) to consume the energy or power of flow and wave, and (3) to drain out the water from the urban areas rapidly. On the contrary, the principles of NBS strategies are: (1) to provide more room back to the water flow, (2) to utilize nature and natural processes, and (3) to increase urban water absorption capacity 
via the storage water environment. These NBS principles are expressed as measures used in different area scales, such as floodplain reconnections, wetland restorations, removing debris in the river, or local practices, such as porous pavement in urban environments, detention basins, rain gardens, oyster reefs, etc.

Table 3. General objectives of flood control in different areas.

\begin{tabular}{ccc}
\hline Aim of Flood Control & Coastal Areas & River Areas \\
\hline $\begin{array}{c}\text { Controlling the amount of water (volume) } \\
\text { Controlling the energy of flow or wave (momentum) }\end{array}$ & $X$ & $X$ \\
\hline
\end{tabular}

Note: $\mathrm{X}$ indicates the objective of flood control in different areas.

Integration between the traditional measures and NBS is sometimes necessary, even though the principles might be contradictory. This is because NBS lack in some areas, such as, NBS cannot be standardized and replicated as efficiently as the traditional solutions. Even though NBS provide high social and environmental benefits to society in theory, their economic efficiency is still argued since traditional infrastructures have been wellaccounted for over decades. Therefore, decision-makers need to evaluate the environmental, social, and economic factors and benefits of NBS, and attempt to find a balance in the infrastructures by combining the hard and the soft measures.

\section{Conclusions}

This study has briefly described the evolution of contemporary flood management in the river, coastal, and built environments. The study recognizes three significant trends in NBS. Firstly, some of the hard measures are being gradually replaced by soft measures. Secondly, society's attention to the ecosystem and their services has increased. Thirdly, multi-functional solutions are being advocated instead of single-function solutions. These slow but steady transformations are triggered by the call for 'resilience' and 'sustainability' in flood defense infrastructure designs. They are fueled by the knowledge related to advanced ecology-related engineering. Many NBS terms used in flood control realms appear, and the literature of these terms shows that studies in this domain have been increasing over the decades.

Although the principles of NBS are different from traditional engineering, their coalition is possible and is considered the mainstream of flood defense strategies. Challenges and barriers of NBS are numerous, but they might disappear over time after more practices and applications are initiated and implemented with constant evaluations in the background. In the meantime, the employment of traditional complex measures and their limitations - especially their lack of resilience to changing climatic or socio-economic conditions-are hard to break through since they have been implemented for a long time. A combination of hard and soft measures has been on the rise for the past few decades, indicating a rapid future transformation of flood defense strategies.

Furthermore, monitoring NBS performance and evaluating the ongoing BwN pilots will be crucial for building the evidence base to support wider uptake of similar projects. This review highlights how NBS are more resilient-based approaches for designing flood defense infrastructure and, at the same time, provide multiple benefits to a wide range of stakeholders, including the local population. They are also cheaper and more sustainable than grey solutions since they can be low maintenance. However, accountability, capacity, and acceptance gaps exist for such approaches since there is a lack of a sturdy framework for designing, implementing, and evaluating these solutions. Natural or man-made conditions preventing their implementation definitely exist and are the barriers to overcome. The review of the literature highlights that an operational framework for NBS should be designed with factors such as the evaluation of direct societal benefits, adaptive governance, consideration of long-term stability of these approaches, ecological complexity, and scale of the ecological organization before implementing a new structure. In addition, continuous 
monitoring and evaluation of the previous projects and adapting to the lessons learned are crucial for sustainable flood management strategies and their societal acceptance.

Author Contributions: Data curation, N.R.; Methodology, Y.-Y.C. and H.-E.C.; Resources, Y.-Y.C. and H.-E.C.; Validation, N.R.; Writing-original draft, Y.-Y.C.; Writing-review and editing, N.R. and H.-E.C. All authors have read and agreed to the published version of the manuscript.

Funding: The "Graduate Students Study Abroad Program" of the Ministry of Science and Technology, Taiwan, R.O.C. partially supports this research under grant No. MOST 106-2917-I-009-013.

Institutional Review Board Statement: Not applicable.

Informed Consent Statement: Not applicable.

Acknowledgments: The authors would also like to thank our co-workers at the Water Science and Engineering Department at IHE Delft, and for being consulted in this research.

Conflicts of Interest: The authors declare no conflict of interest.

\section{References}

1. Hassan, F.A. Water History for Our Times, IHP Essays on Water History No. 2. In International Hydrological Programme; UNESCO: Paris, France, 2010.

2. Wheater, H.; Evans, E. Land Use, Water Management and Future Flood Risk. Land Use Policy 2009, 26 (Suppl. S1), $251-264$. [CrossRef]

3. Wong, P.P.; Losada, I.J.; Gattuso, J.P.; Hinkel, J.; Khattabi, A.; McInnes, K.L.; Saito, Y.; Sallenger, A. Coastal systems and low-lying areas. In Climate Change 2014: Impacts, Adaptation, and Vulnerability. Part A: Global and Sectoral Aspects. Contribution of Working Group II to the Fifth Assessment Report of the Intergovernmental Panel on Climate Change; Cambridge University Press: Cambridge, UK; New York, NY, USA, 2014; pp. 361-409.

4. Narayan, S.; Beck, M.W.; Reguero, B.G.; Losada, I.J.; Van, B.; Lange, M.; Burks-copes, K.A. The Effectiveness, Costs and Coastal Protection Benefits of Natural and Nature-Based Defences. PLoS ONE 2016, 11, e0154735. [CrossRef]

5. MacKinnon, K.; Sobrevila, C.; Hickey, V. Biodiversity, Climate Change, and Adaptation: Nature-Based Solutions from the World Bank Portfolio, No. 46726; The World Bank: Washington, DC, USA, 2008.

6. IUCN. No Time to Lose-Make Full Use of Nature-Based Solutions in the Post-2012 Climate Change Regime. In Position Paper on the Fifteenth Session of the Conference of the Parties to the United Nations Framework Convention on Climate Change (COP 15); International Union for Conservation of Nature: Gland, Switzerland, 2009; pp. 1-5.

7. Bauduceau, N.; Berry, P.; Cecchi, C.; Elmqvist, T.; Fernandez, M.; Hartig, T.; Krull, W.; Mayerhofer, E.; Sandra, N.; Noring, L. Towards an EU Research and Innovation Policy Agenda for Nature-Based Solutions \& Re-Naturing Cities; Final Report of the Horizon 2020 Expert Group on Nature-Based Solutions and Re-Naturing Cities; Publications Office of the European Union: Luxembourg, 2015. [CrossRef]

8. Cohen-Shacham, E.; Walters, G.; Janzen, C.; Maginnis, S. Nature-Based Solutions to Address Societal Challenges; IUCN: Gland, Switzerland, 2016. [CrossRef]

9. Werritty, A. Sustainable Flood Management: Oxymoron or New Paradigm? Area 2006, 38, 16-23. [CrossRef]

10. Mitsch, W.J.; Jørgensen, S.E. Ecological Engineering: A Field Whose Time Has Come. Ecol. Eng. 2003, 20, 363-377. [CrossRef]

11. Mitsch, W.J. Ecological Engineering-The 7-Year Itch. Ecol. Eng. 1998, 10, 119-130. [CrossRef]

12. Grumbles, B. Memorandum: Using Green Infrastructure To Protect Water Quality in Stormwater, CSO, Nonpoint Source and Other Water Programs. United States Environmental Protection Agency, Office of Water. 2007. Available online: http: //water.epa.gov/reg3wapd/npdes/pdf/dcms4_guidance.pdf (accessed on 10 November 2020).

13. Fletcher, T.D.; Shuster, W.; Hunt, W.F.; Ashley, R.; Butler, D.; Arthur, S.; Trowsdale, S.; Barraud, S.; Semadeni-Davies, A.; Bertrand-Krajewski, J.L.; et al. SUDS, LID, BMPs, WSUD and More-The Evolution and Application of Terminology Surrounding Urban Drainage. Urban Water J. 2015, 12, 525-542. [CrossRef]

14. Waterman, R.E. Integrated Coastal Policy via Building with Nature. Ph.D. Thesis, Delft University of Technology, Delft, The Netherlands, 2010; p. 69.

15. Martini, F.; Loat, R. Handbook on Good Practices for Flood Mapping in Europe; EXCIMAP: Brussels, Belgium, 2007.

16. Bruun, P. The History and Philosophy of Coastal Protection. In Proceedings of the Coastal Engineering 1972, Vancouver, BC, Canada, 10-14 July 1972; pp. 33-74.

17. Dornhelm, R. The Coney Island Public Beach and Boardwalk Improvement of 1923. In Proceedings of the Fourth Annual Northeast Shore and Beach Preservation Association Conference (NSBPA), Hoboken, NJ, USA, 24-26 October 2001; pp. 7-11. [CrossRef]

18. Davison, A.T.; Nicholls, R.J.; Leatherman, S.P. Beach Nourishment as a Coastal Management Tool: An Annotated Bibliography on Developments Associated with the Artificial Nourishment of Beaches. J. Coast. Res. 1992, 8, 984-1022. 
19. Charlier, R.H.; Chaineux, M.C.P.; Morcos, S. Panorama of the History of Coastal Protection. J. Coast. Res. 2005, $21,79-111$. [CrossRef]

20. Van Den Bergh, J.C.J.M. Optimal Climate Policy Is a Utopia: From Quantitative to Qualitative Cost-Benefit Analysis. Ecol. Econ. 2004, 48, 385-393. [CrossRef]

21. Stive, M.J.F.; De Vriend, H.J.; Nicholls, R.J.; Capobianco, M. Shore Nourishment and the Active Zone: A Time Scale Dependent View. Coast. Eng. 1992, 1993, 2464-2473.

22. European Commission. Towards a European Integrated Coastal Zone Management (ICZM) Strategy: General Principles and Policy Options; Office for Official Publications of the European Communities: Luxembourg, 1999; p. 5.

23. Field, C.B.; Barros, V.; Stocker, T.F.; Dahe, Q. IPCC-Managing the Risks of Extreme Events and Disasters to Advance Climate Change Adaptation: Special Report of the Intergovernmental Panel on Climate Change; Cambridge University Press: New York, NY, USA, 2012.

24. van Slobbe, E.; de Vriend, H.J.; Aarninkhof, S.; Lulofs, K.; de Vries, M.; Dircke, P. Building with Nature: In Search of Resilient Storm Surge Protection Strategies. Nat. Hazards 2013, 65, 947-966. [CrossRef]

25. Temmerman, S.; Meire, P.; Bouma, T.J.; Herman, P.M.J.; Ysebaert, T.; De Vriend, H.J. Ecosystem-Based Coastal Defence in the Face of Global Change. Nature 2013, 504, 79-83. [CrossRef] [PubMed]

26. de Vriend, H.; van Koningsveld, M.; Aarninkhof, S. "Building with Nature": The New Dutch Approach to Coastal and River Works. Proc. Inst. Civ. Eng. Civ. Eng. 2014, 167, 18-24. [CrossRef]

27. de Vriend, H.J.; van Koningsveld, M.; Aarninkhof, S.G.J.; de Vries, M.B.; Baptist, M.J. Sustainable Hydraulic Engineering through Building with Nature. J. Hydro-Environ. Res. 2015, 9, 159-171. [CrossRef]

28. Hoekstra, R.; Walstra, D.-J.R.; Swinkels, C.S. Pilot Project Sand Groynes Delfland Coast. In ICCE 2012: Proceedings of the 33rd International Conference on Coastal Engineering; Coastal Engineering Research Council: Santander, Spain, 2012.

29. Taal, M.; Löffler, M.A.; Vertegaal, C.T.; Wijsman, J.W.; Van der Valk, L.; Tonnon, P. Development of the Sand Motor; Delft University Publishers: Delft, The Netherlands, 2016.

30. Speed, R.A.; Li, Y.; Tickner, D.; Huang, H.; Naiman, R.J.; Cao, J.; Lei, G.; Yu, L.; Sayers, P.; Zhao, Z. A Framework for Strategic River Restoration in China. Water Int. 2016, 41, 998-1015. [CrossRef]

31. Koebel, J.W. An Historical Perspective on the Kissimmee River Restoration Project. Restor. Ecol. 1995, 3, 149-159. [CrossRef]

32. Nienhuis, P.H.; Leuven, R. River Restoration and Flood Protection: Controversy or Synergism? Hydrobiologia 2001, 444, 85-99. [CrossRef]

33. DeLaney, T.A. Benefits to Downstream Flood Attenuation and Water Quality as a Result of Constructed Wetlands in Agricultural Landscapes. J. Soil Water Conserv. 1995, 50, 620-626.

34. Hey, D.L.; Phillippi, N.S. Flood reduction through wetland restoration: The Upper Mississippi River Basin as a case history. Restor. Ecol. 1995, 3, 4-17. [CrossRef]

35. Hallegatte, S. Strategies to Adapt to an Uncertain Climate Change. Glob. Environ. Chang. 2009, 19, 240-247. [CrossRef]

36. Kabisch, N.; Korn, H.; Stadler, J.; Bonn, A. Nature-Based Solutions to Climate Change Adaptation in Urban Areas; Theory and Practice of Urban Sustainability Transitions; Springer: Berlin/Heidelberg, Germany, 2017. [CrossRef]

37. van Herk, S.; Rijke, J.; Zevenbergen, C.; Ashley, R.; Besseling, B. Adaptive Co-Management and Network Learning in the Room for the River Programme. J. Environ. Plan. Manag. 2015, 58, 554-575. [CrossRef]

38. Rijke, J.; van Herk, S.; Zevenbergen, C.; Ashley, R. Room for the River: Delivering Integrated River Basin Management in the Netherlands. Int. J. River Basin Manag. 2012, 10, 369-382. [CrossRef]

39. Chocat, B.; Krebs, P.; Marsalek, J.; Rauch, W.; Schilling, W. Urban Drainage Redefined: From Stormwater Removal to Integrated Management. Water Sci. Technol. 2001, 43, 61-68. [CrossRef] [PubMed]

40. Burian, S.J.; Edwards, F.G. Historical Perspectives of Urban Drainage. In Global Solutions for Urban Drainage; Steven, J., Burian, S.J., Findlay, G., Edwards, F.G., Eds.; American Society of Civil Engineers: Reston, VA, USA, 2002; pp. 1-16.

41. Burian, S.; Edwards, F. Historical Perspectives of Urban Drainage. Global Solutions for Urban Drainage. In Global Solutions for Urban Drainage. In Proceedings of the Ninth International Conference on Urban Drainage (9ICUD), Lloyd Center Doubletree Hotel, Portland, OR, USA, 8-13 September 2002; Strecker, E.W., Huber, W.C., Eds.; American Society of Civil Engineers: Reston, VA, USA, 2002; pp. 1-16.

42. National Research Council. Prospects for Managed Underground Storage of Recoverable Water; National Academies Press: Washington, DC, USA, 2008.

43. Wanielista, M.P.; Yousef, Y.A. Stormwater Management; John Wiley\& Sons. Inc.: New York, NY, USA, $1993 ;$ p. 579.

44. Yang, B.; Li, M.H.; Li, S. Design-with-Nature for Multi-functional Landscapes: Environmental Benefits and Social Barriers in Community Development. Int. J. Environ. Res. Public Health 2013, 10, 5433-5458. [CrossRef]

45. Mguni, P.; Herslund, L.; Jensen, M.B. Sustainable Urban Drainage Systems: Examining the Potential for Green Infrastructure-Based Stormwater Management for Sub-Saharan Cities. Nat. Hazards 2016, 82, 241-257. [CrossRef]

46. Raymond, C.M.; Pam, B.; Breil, M.; Nita, M.R.; Kabisch, N.; de Bel, M.; Enzi, V.; Frantzeskaki, N.; Geneletti, D.; Cardinaletti, M.; et al. An Impact Evaluation Framework to Support Planning and Evaluation of Nature-Based Solutions Projects; Centre for Ecology and Hydrology: Lancaster, UK, 2017. [CrossRef]

47. Zhou, Q. A Review of Sustainable Urban Drainage Systems Considering the Climate Change and Urbanization Impacts. Water 2014, 6, 976-992. [CrossRef] 
48. Miguez, M.G.; Rezende, O.M.; Veról, A.P. City Growth and Urban Drainage Alternatives: Sustainability Challenge. J. Urban Plan. Dev. 2015, 141, 4014026. [CrossRef]

49. Klijn, F.; De Bruijn, K.; Ölfert, A.; Penning-Rowsell, E.C.; Simm, J.; Wallis, M. Flood Risk Assessment and Flood Risk Management: An Introduction and Guidance Based on Experiences and Findings of FLOODsite (an EU-Funded Integrated Project); FLOODsite; Deltares: Delft, The Netherlands, 2009; ISBN 9789081406710.

50. Elliott, A.H.; Trowsdale, S.A. A Review of Models for Low Impact Urban Stormwater Drainage. Environ. Model. Softw. 2007, 22, 394-405. [CrossRef]

51. Sayers, P.; Galloway, G.; Penning-Rowsell, E.; Yuanyuan, L.; Fuxin, S.; Yiwei, C.; Kang, W.; Le Quesne, T.; Wang, L.; Guan, Y. Strategic Flood Management: Ten 'Golden Rules' to Guide a Sound Approach. Int. J. River Basin Manag. 2015, 13, 137-151. [CrossRef]

52. Wright, J.M. The Nation's Responses To Flood Disasters: A Historical Account; USA Paul Osman illinois Publication: Chicago, IL, USA, 2000.

53. Disco, C. Remaking "Nature": The Ecological Turn in Dutch Water Management. Sci. Technol. Hum. Values 2002, $27,206-235$. [CrossRef]

54. Hamm, L.; Capobianco, M.; Dette, H.H.; Lechuga, A.; Spanhoff, R.; Stive, M.J.F. A Summary of European Experience with Shore Nourishment. Coast. Eng. 2002, 47, 237-264. [CrossRef]

55. Luo, P.; He, B.; Takara, K.; Xiong, Y.E.; Nover, D.; Duan, W.; Fukushi, K. Historical Assessment of Chinese and Japanese Flood Management Policies and Implications for Managing Future Floods. Environ. Sci. Policy 2015, 48, 265-277. [CrossRef]

56. Xia, J.; Zhang, Y.; Xiong, L.; He, S.; Wang, L.; Yu, Z. Opportunities and Challenges of the Sponge City Construction Related to Urban Water Issues in China. Sci. China Earth Sci. 2017, 60, 652-658. [CrossRef]

57. Kundzewicz, Z.W.; Takeuchi, K. Flood Protection and Management: Quo Vadimus? Hydrol. Sci. J. 1999, 44, 417-432. [CrossRef]

58. Brink, E.; Aalders, T.; Ádám, D.; Feller, R.; Henselek, Y.; Hoffmann, A.; Ibe, K.; Matthey-Doret, A.; Meyer, M.; Negrut, N.L. Cascades of Green: A Review of Ecosystem-Based Adaptation in Urban Areas. Glob. Environ. Chang. 2016, 36, 111-123. [CrossRef]

59. Geneletti, D.; Zardo, L. Ecosystem-Based Adaptation in Cities: An Analysis of European Urban Climate Adaptation Plans. Land Use Policy 2016, 50, 38-47. [CrossRef]

60. Kabisch, N.; Frantzeskaki, N.; Pauleit, S.; Naumann, S.; Davis, M.; Artmann, M.; Haase, D.; Knapp, S.; Korn, H.; Stadler, J.; et al. Nature-Based Solutions to Climate Change Mitigation and Adaptation in Urban Areas and Their Rural Surroundings. Ecol. Soc. 2016, 21, 39. [CrossRef]

61. Williams, K.; Gupta, R.; Hopkins, D.; Gregg, M.; Payne, C.; Joynt, J.L.R.; Smith, I.; Bates-Brkljac, N. Retrofitting England's Suburbs to Adapt to Climate Change. Build. Res. Inf. 2013, 41, 517-531. [CrossRef]

62. Keeley, M.; Koburger, A.; Dolowitz, D.P.; Medearis, D.; Nickel, D.; Shuster, W. Perspectives on the Use of Green Infrastructure for Stormwater Management in Cleveland and Milwaukee. Environ. Manag. 2013, 51, 1093-1108. [CrossRef] [PubMed]

63. Hildebrandt, E.W.; Sarkovich, M. Assessing the Cost-Effectiveness of SMUD's Shade Tree Program. Atmos. Environ. 1998, 32, 85-94. [CrossRef]

64. Hill, E.; Dorfman, J.H.; Kramer, E. Evaluating the Impact of Government Land Use Policies on Tree Canopy Coverage. Land Use Policy 2010, 27, 407-414. [CrossRef]

65. Iacob, O.; Rowan, J.S.; Brown, I.; Ellis, C. Evaluating Wider Benefits of Natural Flood Management Strategies: An Ecosystem-Based Adaptation Perspective. Hydrol. Res. 2014, 45, 774-787. [CrossRef]

66. Santoro, S.; Pluchinotta, I.; Pagano, A.; Pengal, P.; Cokan, B.; Giordano, R. Assessing Stakeholders' Risk Perception to Promote Nature Based Solutions as Flood Protection Strategies: The Case of the Glinščica River (Slovenia). Sci. Total Environ. 2019, 655, 188-201. [CrossRef] [PubMed]

67. Shrubsole, D. From structures to sustainability: A history of flood management strategies in Canada. Int. J. Emerg. Manag. 2007, 4, 183-196. [CrossRef]

68. Burns, M.J.; Fletcher, T.D.; Walsh, C.J.; Ladson, A.R.; Hatt, B.E. Hydrologic shortcomings of conventional urban stormwater management and opportunities for reform. Landsc. Urban Plan. 2012, 105, 230-240. [CrossRef]

69. Van Stokkom, H.T.; Smits, A.J.; Leuven, R.S. Flood defense in the Netherlands: A new era, a new approach. Water Int. 2005, 30, 76-87. [CrossRef] 